\title{
INFLUENCE OF FEEDING OF FRIESIAN CALVES ON COW'S MILK ON MEAT AND FAT QUALITIES AND SOME COOKING PROPERTIES
}

\author{
Elsanat, S. Y. ${ }^{1}$; M. A. Abu El-Hamd ${ }^{2}$; Mervat E. El-Demery ${ }^{3}$ and
}

A. M. Salama ${ }^{4}$

1 Food Technology Dept., Fac. Agric. Kafrelsheikh Univ., Egypt.

2,4 Animal Production Res. Inst., Agric. Res. center, Giza, Egypt.

3 Home Economics Dept., Fac. Specific Education Kafrelsheikh Univ., Egypt

\begin{abstract}
The effect of a diet with cow's milk fed "CM-F" on the newly born male Friesian calves meat and fat quality as well as its chemical composition was studied. Longissimus dorsi muscles were collected from a total 12 Friesian calves fed on diets containing concentrated feed mixture (CFM) (control) as well as liquid cow milk fed (MF) (treatment). The meat and fats quality of muscles were evaluated, the fats includes the cooking and palatability traits. The muscles were subjected to different cooking treatment (blanching and blanching-frying), then evaluated chemically and organoleptically. Breeding exerted a major influence on meat quality (cooking, and palatability traits). Raw and cooked meat quality (moisture, protein, lipids, ash, meat color, $\mathrm{pH}$ and water retention capacity) and eating quality of cooked meat (odor, flavor and texture) were determined. The Milk fed (MF) group exhibited a higher fat percentage, lower water holding capacity, and cooking losses, and higher scores for tenderness and juiciness than the CFM group. The percentage of saturated fatty acids was higher in the MF group. Although juiciness was negatively correlated with cooking loss, meat from CFM received the highest ratings for juiciness, despite sustaining the greatest cooking losses. The results suggest that milk use in veal production, produced palatable meat, and could be an advantageous alternative in terms on meat and fat quality.

Keywords: Veal calves; liquid milk feeding; Fatty acids composition; meat characteristics; consumer acceptability.
\end{abstract}

\section{INTRODUCTION}

The ultimate success of any product in the market-place is dependent upon its acceptability to consumers. Consumer acceptability of meat is dependent upon the appearance of the product at the point of purchase and the satisfaction derived at the point of consumption. However, emphasis over the past five decades has been placed on producing the most meat at the lowest cost little regard for the quality of the product. Consequently, meat market position could be strengthened considerably by placing emphasis on quality to improve consumer acceptance Jeremiah et al. (1999).

In fact, the type of diet did affect other attributes of the meat such as intramuscular fat, cholesterol, collagen, muscular pigments, and $\mathrm{pH}$ or water retention capacity. The fat composition of depots can affect the appearance, 
color and odor of raw meat. Cooking loss is of interest because it is expected to explain part of the variation in juiciness but also because it influences the appearance of the meat. A high cooking loss gives an expectation of a less optimal eating quality. Cooking loss is also of great economic importance to the catering industry. Against this background, a better understanding of the sensory attribute juiciness and of cooking loss and how they interact is important not only to optimize the eating quality of beef, but also for economic reasons. Although there are no sensory studies about the effects of lactation on beef calves meat, considering the above, it is probable that diet can affect some sensory attributes of the cooked meat Tornberg (2005) and Banón et al.( 2006).

During cooking, the consumer observes some shrinkage often thought to be an indicator of poor meat quality and/or the effect of hormone treatments. The cooking loss, tenderness and shrinkage, despite being different expressions of the same phenomenon, are perceived by the consumer as different events because they are observed in different time frames. Often purchasing, cooling, cooking and eating are done by different people, therefore supporting a separate vision of the phenomenon Barbera and Tassone (2006).

Therefore ,this study was carried out to study the effect of type of feeding on the quality attributes of calves beef, fatty acid composition of beef fats and meat cooking properties.

\section{MATERIALS AND METHODS}

\section{Materials:}

Experimental animals was born in Sakha Animal Production Station, Animal Production Research Institute (APRI), fresh caw's milk was obtained from caws which breeding in the same Station, starter was obtained from factory of concentrate feed mixture, Shosha, El-Minia Governorate, Egypt and berseem hay was obtained from Agricultural Research Center fields in Kafrelshiekh Governorate.

This study was carried out at Sakha Animal Production Station, Animal Production Research Institute (APRI), Agricultural Research Center. Twelve newly born male Friesian calves were assigned into two similar groups according to their birth weight.

\section{Methods:}

\section{Experimental ration:}

Calves in (G1) were given fresh whole milk up to 105 day of age (suckling period) plus starter and berseam hay (solid feeds) from the third week up to 180 day of age. While, calves in (G2) were raised on fresh whole milk only up to 180 day of age. Calves were fed to cover their requirements according to NRC (1996).

The daily feeding scheme during experimental period is shown in Table (1). All calves were given milk in plastic bucket 2-5 times daily according to their quantity as shown in Table (2). Calves were fed individually 
and daily feed intake was adjusted according to body weight change. Mineral blocks are available during the whole experimental period and drinking water was available at all the time. Chemical analysis of feedstuff used in this experiment are presented in Table (3) that was carried out according to A.O.A.C (2000).

Table (1): Daily feeding scheme of experimental calves

\begin{tabular}{|c|c|c|c|c|}
\hline \multirow{2}{*}{\begin{tabular}{|l} 
Age \\
(week)
\end{tabular}} & \multicolumn{3}{|c|}{ G1 } & \multirow{2}{*}{$\begin{array}{c}\text { G2 } \\
\text { Fresh milk (Kg) }\end{array}$} \\
\hline & Fresh milk (Kg) & Starter (Kg) & Berseem hay $(\mathrm{Kg})$ & \\
\hline 1 & 4.00 & ---- & ----- & 4 \\
\hline 2 & 4.00 & $\begin{array}{ll}--- \\
\end{array}$ & $\begin{array}{ll}---- \\
\end{array}$ & 4 \\
\hline 3 & 5.00 & 0.250 & 0.125 & 6 \\
\hline 4 & 5.00 & 0.250 & 0.125 & 6 \\
\hline 5 & 6.00 & 0.500 & 0.250 & 7 \\
\hline 6 & 6.00 & 0.500 & 0.250 & 7 \\
\hline 7 & 5.50 & 0.750 & 0.500 & 8 \\
\hline 8 & 5.00 & 0.750 & 0.500 & 10 \\
\hline 9 & 4.00 & 1.000 & 0.750 & 10 \\
\hline 10 & 3.00 & 1.000 & 0.750 & 12 \\
\hline 11 & 2.50 & 1.250 & 1.000 & 12 \\
\hline 12 & 2.00 & 1.250 & 1.000 & 13 \\
\hline 13 & 1.50 & 1.500 & 1.250 & 13 \\
\hline 14 & 1.50 & 1.500 & 1.250 & 13 \\
\hline 15 & 1.00 & 1.750 & 1.500 & 14 \\
\hline 16 & - & 1.750 & 1.500 & 14 \\
\hline 17 & - & 2.000 & 1.750 & 15 \\
\hline 18 & - & 2.250 & 1.750 & 15 \\
\hline 19 & - & 2.500 & 2.000 & 16 \\
\hline 20 & - & 2.600 & 2.000 & 16 \\
\hline 21 & - & 2.850 & 2.250 & 17 \\
\hline 22 & - & 3.000 & 2.250 & 18 \\
\hline 23 & - & 3.250 & 2.500 & 19 \\
\hline 24 & - & 3.450 & 2.500 & 20 \\
\hline
\end{tabular}

Table (2): Number and time of fresh milk diets $(\mathrm{kg})$ per day offered to experimental calves

\begin{tabular}{|l|c|c|c|c|c|}
\hline \multirow{2}{*}{$\begin{array}{l}\text { Milk } \\
(\mathbf{k g})\end{array}$} & quantity & \multicolumn{5}{|c|}{ Times } \\
\cline { 2 - 6 } & First & Second & third & Fourth & Fives \\
\hline $\mathbf{4 - 6}$ & $7 \mathrm{am}$ & $6 \mathrm{pm}$ & ----- & ----- & ----- \\
\hline $\mathbf{7 - 1 2}$ & $7 \mathrm{am}$ & $12 \mathrm{am}$ & $6 \mathrm{pm}$ & ------ & ----- \\
\hline $\mathbf{1 2 - 1 6}$ & $7 \mathrm{am}$ & $11 \mathrm{am}$ & $3 \mathrm{pm}$ & $6 \mathrm{pm}$ & \\
\hline $\mathbf{1 6 - 1 8}$ & $7 \mathrm{am}$ & $11 \mathrm{am}$ & $3 \mathrm{pm}$ & $6 \mathrm{pm}$ & $8 \mathrm{pm}$ \\
\hline
\end{tabular}


Elsanat, S. Y. et al.

Table (3): Chemical analysis of experimental feed stuff (\% on dry weight basis).

\begin{tabular}{|c|c|c|c|}
\hline \multirow{2}{*}{$\begin{array}{c}\text { Chemical composition } \\
(\%)\end{array}$} & \multicolumn{3}{|c|}{ Feed materials } \\
\hline & Fresh milk & Starter* & Berseem hay \\
\hline Dry matter & 12.8 & 91.3 & 88.3 \\
\hline Organic matter & 94.4 & 90.3 & 88.3 \\
\hline Crude protein & 24.4 & 17.0 & 15.3 \\
\hline Crude fiber & 00.0 & 11.9 & 24.2 \\
\hline Ether extract & 30.6 & 5.0 & 6.1 \\
\hline Nitrogen free extract (NFE) & 39.4 & 56.4 & 42.2 \\
\hline Ash content & 5.6 & 9.7 & 11.7 \\
\hline
\end{tabular}

${ }^{*}$ The starter feed used in this study was composed of $37.5 \%$ yellow corn, $20 \%$ soybean meal, $15 \%$ corn gluten, $22.5 \%$ wheat bran, $3 \%$ molasses. $0.5 \%$ premix and $1.5 \%$ common salt.

\section{Management:}

Calves were kept in individual pens, they move to loose yard few hours a day. To avoid diarrhea causing gastroenteritis, $30 \mathrm{ml}$ per $25 \mathrm{~kg}$ live body weight from Scourban treatment was introduced orally to experimental calves two times during experimental period with two months intervals Scourban treatment contains Sulphadimidine, Sulphaguanidine, Streptromycin sulphate, neotemycin sulpha and Starvuta- Multi-Oligo as commercial feed additives dissolved in fresh milk, also, it contains vitamins A, D3, E, B2, B6, nicotinic acid, folic acid, vitamin C, K3, biotin and some minerals (Iron, copper, Zinc, gm/ manganese, cobalt. and cholin). Any noticed diarrhea was treated on time. Calves were weight biweekly in the morning before watered and feeding to calculate live daily gain. Relative growth was calculated according to the following formula: (final weight - Initial weigh / initial weight) X 100 (Abu El-Hamd, 2003)

\section{Slaughtering characteristics:}

At the end of the feeding trials (6 months), all calves were slaughtered at a mean weight of $200 \mathrm{~kg}$, Before slaughtering calves were weighed after fasting period of 16 hours. Upon all calves were rested for at least $3 \mathrm{~h}$ prior to slaughtering. All carcasses were chilled for $20 \mathrm{~h}$ at $2^{\circ} \mathrm{C}$. The Longissimus dorsi muscle of each carcass was then transferred to the Food Science and Technology Department, Faculty of Agriculture, Kafrelsheikh University.

Longissimus dorsi muscle area was measured with planimeter in $\mathrm{Cm}^{2}$, subcutaneous fat thickens using calipers and specific gravity was calculated by the following equation:

$$
\text { Specific gravity }=\quad \frac{W_{1}}{W 2}
$$

Whereas W1 was weight of meat cut in air and W2 was weight in water, as described by US D A (1975). Tenderness and water-holding capacity were measured using the Volovinskaia and Merkolova (1958) method. The color intensity of meat extract was measured at $542 \mathrm{~nm}$ by spectrophotometer according the method described by Husaini et al. (1950). Value of $\mathrm{pH}$ was 
measured according to the method of Aitken et al. (1962) by using digital pHmeter (Jenway, 3010) at room temperature.

Chemical analysis:

Moisture; crude protein; ether extract; and ash contents of raw, boiled and boiled-fried meat were determined according to the methods of the $\operatorname{AOAC}(2000)$.

The total soluble nitrogen (TSN) was determined according to the method mentioned in AOAC (2000); non protein nitrogen (NPN) was determined according to the method described by Jacobs (1962) and the percentage of soluble nitrogen was calculated by subtracting the percentage of non protein nitrogen from the percentage of total soluble nitrogen value of the same extract. Caloric values were calculated by multiplying protein content by 4 and lipid content by 9 as reported by Liu et al. (1990).

\section{Cooking procedure:}

Two cooking procedures were used as follow:

Blanching: Three samples of Longissimus dorsi muscle $(100 \mathrm{gm})$ at a time were cooked in boiling water $(400 \mathrm{ml})$ at $115^{\circ} \mathrm{C}$ for $45 \mathrm{~min}$.

Blanching-Frying: After boiling the meat samples were fried in corn oil at $180^{\circ} \mathrm{C}$ for 5 min. according to the conditions mentioned by Abd El-Aal et al. (2000).

\section{Cooking traits (meat cooking shrinkage (MCS) and cooking loss} (CLmsc)):

The cooked samples were cooled at room temperature $\left(25^{\circ} \mathrm{C}\right)$ and after $20 \mathrm{~min}$ from the end of cooking,then they were weighed (CW) and the cooked area measured (CA). The method uses a disk of meat $(5 \mathrm{~cm}$ thick and $10 \mathrm{~cm}$ wide) measured before and after cooking. Samples were not measured immediately after cooking as it was difficult to manipulate them with a high risk of deformation and a rapid change in area. In addition, due to the simple procedure, samples were also weighed when measured which allowed a measurement of cooking loss (CLmcs) to be recorded at the same time. The measurement of area on each raw and cooked sample was repeated three times. Barbera and Tassone (2006).

Meat cooking shrinkage (MCS) value indicates the area sample shrinkage caused by cooking was calculated as follows:

$\operatorname{MCS}(\%)=\frac{\mathrm{RA}-\mathrm{CA}}{\mathrm{RA}} \times 100$

Whereas RA was raw area measured and CA was cooked area measured.

Cooking loss value indicates the weight of the water loss caused by the meat cooking shrinkage procedure (CLmcs) was calculated as:

$$
\text { CLmcs }(\%)=\frac{\mathrm{RW}-\mathrm{CW}}{\mathrm{RW}} \times 100
$$

Whereas RW was raw weight and CW was cooked weight.

Fatty acid composition:

The fatty acid profile of raw samples was determined by gas chromatography (Perkin-Elmer Auto syst-X.L) after the methylesters were estimated after passed from oven-filtered fat AOAC (2000). Lipid extraction 
from longissimus dorsi muscle and methylesters preparation were carried out according to the method of Morrison and Smith (1964).

\section{Sensory evaluation:}

The cooked samples were evaluated organoleptically. Twenty different untrained panelists from staff members of the Food Technology, Fac. of Agriculture, Kafrelsheikh University and Sakha Animal Production Research Station, were used at the panel session. Panelists were asked to judge the samples about flavor, tenderness, juiciness and overall acceptability as described by Chambaz et al. (2003) using a 5-point scale for grading the quality of samples (tenderness. $1=$ very tough. $5=$ tender, juiciness. $1=$ very dry. 5 = juicy, flavor, 1 = extremely unacceptable. 5 = very acceptable. Tenderness was measured after three chews, juiciness was measured after five chews, and flavor was measured after eight chews.

\section{Statistical analysis:}

Data obtained in this study were statistically analyzed according to T-test models procedure adapted by SPSS (1997).

\section{RESULTS AND DISCUSSION}

\section{Gross chemical composition of raw meat:}

Table (4) shows the proximate composition of the Longissimus dorsi muscle determined on diet. The beef calves produced very lean meat, high in moisture and protein, but low in intramuscular fat (marbling) and ash contents. The intramuscular fat is the primary criterion for quality grading of beef carcass quality and also is a suitable indicator of meat tenderness Chambaz et al.( 2003). Meat of calves fed with CFM contained significantly $(P<0.01)$ more water, fat and ash and significantly $(P<0.05)$ less fat than calves fed with cow's milk (MF) meat. Such difference my be attributed to differences in type of food. Caloric value increased in treated calves as affected by dietary fat and the differences can be attributed to differences in fat content as reported by Erickson et al. (1981).

Table (4): Gross chemical composition of Longissimus dorsi (LD) muscles collected from Friesian calves fed with concentrate feed mixture CFM (Control) or cow's milk (MF) (\%on dry weight basis).

\begin{tabular}{|l|c|c|c|}
\hline \multirow{2}{*}{ Parameter } & \multicolumn{2}{|c|}{ Raw meat } & \multirow{2}{*}{ Signifiance } \\
\cline { 3 - 4 } & $\begin{array}{c}\text { CFM fed } \\
\text { (Control) }\end{array}$ & Milk fed (MF) & \\
\hline Moisture $(\%)$ & 75.03 & 72.78 & ${ }^{*}$ \\
\hline Dry matter $\quad(\%)$ & 24.97 & 27.22 & ${ }^{*}$ \\
\hline Crude protein (\%) & 86.85 & 86.82 & NS \\
\hline Ether extract (\%) & 5.87 & 6.84 & ${ }^{*}$ \\
\hline Ash content (\%) & 6.88 & 6.32 & NS \\
\hline Caloric value (Kcal/100g) & 400.23 & 408.84 & ${ }^{*}$ \\
\hline
\end{tabular}




\section{Physical characteristics of Longissimus dorsi muscle}

Longissimus dorsi (LD) muscle area of Friesian calves fed on control ration and cow's milk was 75.59 and $76.80 \mathrm{Cm}^{2}$, respectively Table (5). The differences between two treatments were significant at $(P<0.05)$ and they may be attributed to the variation in carcass weight, edible meat percentage and the marbling of carcass. These results are in agreement with those obtained by Nigm ( 1979) and El-Sharkawy (2006), who found that LD muscle area of Friesian calves ranged from 54.41 to $93.76 \mathrm{Cm}^{2}$.

Table (5): Physical characteristics of Longissimus dorsi (LD) muscles collected from Friesian calves fed with CFM (Control) and these fed with cow's milk (MF).

\begin{tabular}{|c|c|c|c|}
\hline Characteristics & $\begin{array}{l}\text { Concentrated } \\
\text { fed (CFM) }\end{array}$ & $\begin{array}{l}\text { Milk fed } \\
\text { (MF) }\end{array}$ & Significance \\
\hline Longissiumus dorsi muscle area $\left(\mathrm{Cm}^{2}\right)$ & 75.59 & 76.80 & * \\
\hline Fat thickness (mm) & 1.72 & 1.75 & Ns \\
\hline Tenderness $\left(\mathrm{cm}^{2}\right)$ & 3.40 & 3.25 & Ns \\
\hline Water holding capacity $\left(\mathrm{cm}^{2}\right)$ & 7.65 & 7.22 & * \\
\hline Color intensity (O.D) & 0.36 & 0.31 & * \\
\hline Specific gravity & 1.06 & 1.04 & Ns \\
\hline pH value & 5.95 & 5.74 & * \\
\hline
\end{tabular}

NS: not significant

Data of Table (5) shows that, the values of subcutaneous fat thickness (fat depth over Longissimus dorsi muscle) of Friesian calves fed on the experimental rations were not significantly affected by feed supplementation. These results are within those obtained by El-Sharkawy (2006).

In respect of tenderness, values of the meat of calves fed on control ration and group fed on cow's milk were 3.40 and $3.25 \mathrm{Cm}^{2}$, respectively. The differences between control and treatment were not significant. The differences in tenderness might due to variations in moisture content in meat, differences of fiber diameter, amount of connective tissues and protein solubility.

Regarding water-holding capacity (WHC), no significant effects of milk intake, since the WHC values of meat of calves fed on CFM ration and fed on MF were 7.65 and $7.22 \mathrm{Cm}^{2}$, respectively. The slight decrease of WHC may be due to the decrease of $\mathrm{pH}$ value towards the isoelectric point of muscle proteins as well as the association of actin and myosin leading to decrease of solubility and decrease of free chemical groups that are able to bind water Rao et al., (1989) reported that WHC increased over the $\mathrm{pH}$ ranged between 4.0 and 5.1. The water holding capacity (WHC) of the meat might also influence the juiciness independent of $\mathrm{pH}$, but this is not quite clear. The higher water-holding capacity observed for calves receiving CFM fed is consistent with the findings of Scheeder et al.(1999) and Vieira et al. (2005).

Color intensity decreased significantly in the case of meat of calves fed on cow's milk than control CFM. The obtained results are agreed with those 
Mehany (1999) and El-Sarkawy (2006), who found that the color intensity Friesian. Eye muscle ranged from 0.331 to 0.768 . CFM meat was also slightly redden $(P<0.05)$. This could be related to its lower water content, since the concentration of muscular pigment and $\mathrm{pH}$ values were different in CFM and CM meat. Similar results were reported by Banón et al. (2006). The feeding on CFM (control) and caw milk diets FM had a slight effect on the raw meat quality, modifying only the water/protein ratio and the color. It is accepted that young animals yield pale meat with more water and less protein, Marichal et al. (2003) and Banón et al. (2006).

The $\mathrm{pH}$ of CFM was higher than $\mathrm{pH}$ of MF (5.95 and 5.74). Beef calf meat was very lean, rich in water and with little connective tissue. It was pale red in color, its $\mathrm{pH}$ was similar to calves and it had a high water retention capacity, typical of the meat of young animals. This has been observed by (Todaro et al., 2002; Marichal et al., 2003 and Banón et al., 2006).

Nitrogenous compounds:

The total soluble nitrogen, soluble protein nitrogen and non protein nitrogen content of Longissimus dorsi muscle meat of Friesian calves fed on the experimental rations CFM and supplemented with milk MF are given in Table (6).

Table (6): Some nitrogenous components of Longissimus dorsi muscle meat of Friesian calves fed on CFM (Control) or cow's milk fed MF.

\begin{tabular}{|c|c|c|c|}
\hline $\begin{array}{l}\text { Constituents type of feeding } \\
\text { Characteristics }\end{array}$ & CFM & MF & significant \\
\hline uble nitrogen (\%) & 2.43 & 2.35 & * \\
\hline tein nitrogen (\%) & 0.62 & 0.55 & * \\
\hline Soluble protein nitrogen (\%) & 1.75 & 1.65 & * \\
\hline
\end{tabular}

*Significant at $\mathrm{P}>0.05$

Data of Table $(6)$ shows a significant difference at $(P<0.05)$ between $\mathrm{CFM}$ and MF, whereas the highest value was found in CFM. The increase of protein solubility could be due to the breakdown and proteolysis of the muscle proteins to other nitrogen forms as well as the association of actomyocin into actin and myosin El-Sharkawy (2006).

Fatty acid composition:

Results of gas chromatographic analysis of the methyl esters of saturated and unsaturated fatty acids of longissimus muscles of control CFM and treated calves MF are presented in Table (7). The results show that longissimus muscles of control had higher unsaturated fatty acids than those of calves fed on cow's milk.

The results from the same table indicate that the predominant unsaturated fatty acid in control meat was linoleic acid ,while in the treatment meat was oleic acid. On the other hand, total essential fatty acids were 43.62 and $17.99 \%$ for longssimus muscles obtained from control and treatment, respectively. 
Table (7): Fatty acids profile of Longissimus dorsi muscle meat of Friesian calves as affected by diet composition (milk supplementation "MF" or concentrate feed mixture "CFM"(\% of fatty acids).

\begin{tabular}{|l|c|c|c|}
\hline \multicolumn{1}{|c|}{ Fatty acids } & $\begin{array}{c}\text { Concentrated fed } \\
\text { (CFM) }\end{array}$ & $\begin{array}{c}\text { Milk fed } \\
\text { (MF) }\end{array}$ & significant \\
\hline Unsaturated fatty acids: & 4.14 & 26.21 & ${ }^{* *}$ \\
Oleic acid (C18:1) & 40.56 & 8.77 & ${ }^{* *}$ \\
Linoleic (C18:2) & 3.06 & 9.22 & ${ }^{*}$ \\
Linolenic (C18:3) & 4.14 & 26.21 & ${ }^{* *}$ \\
\hline Total monoenoic fatty acids\% & 43.62 & 17.99 & ${ }^{* *}$ \\
\hline Total polyenoic fatty acids (EFA)\% & 47.76 & 44.20 & ${ }^{*}$ \\
\hline Total unsaturated fatty acids\% & 3.32 & & \\
\hline Saturated fatty acids & 27.69 & 24.93 & ${ }^{* *}$ \\
Myristic acid (C14:0) & 21.24 & 29.59 & ${ }^{* *}$ \\
Palmitic acid (C16:0) & 52.25 & 55.8 & ${ }^{* *}$ \\
Stearic acid (C18:0) & 0.91 & 0.79 & ${ }^{*}$ \\
\hline Total saturated fatty acids &
\end{tabular}

EFA= Essential fatty acids. ${ }^{*}$ Significant at $P>0.05{ }^{* *}$ Significant at $P>0.01$

These results revealed that longissimus from control are better than treatment for nutrition especially from the view point of total essential fatty acids. Saturated fatty acids of longssimus muscles from control are lower than treatment.

As expected, animals receiving milk daily till slaughteris had higher percentages of short- and medium-chain fatty acids. A similar fatty-acid profile to that found in this study has been reported by Hornick et al. (1996) and Vieira et al. (2005) in calves whose diet included a milk supplement until slaughter. This fatty acid profile is a consequence of milk fatty acids being scarcely altered on passing through the rumem (owing to the oesophageal groove closure reflex) and my be reflected to a greater extent in composition of body fat deposits (Xiccato et al., 2002; Vieira et al., 2005 and Banón et al. 2006). Alternatively, the fatty acid profile obtained in the CFM group is consistent with reports by several authors working with calves fed a milk diet over varying perods of time and later fed a concentrate diet Hornick et al. (1996) and Vieira et al. (2005).

The greater presence of polyunsaturated fatty acids in fat from CFM group could be partially explained by the fact that these animals consumed a larger amount of concentrate. The raw materials employed in concentrate formulation have a relatively high percentage of polyunsaturated fatty acidslinoleic being promint. According to our observations, most studies in which sources of polyunsaturated fatty acids have been incorporated in the diet agree that, the despite the transformation occurring in the rumen, the composition of the different body fat deposits may be governed by dietary composition Demeyer( 1999) and Vieira et al. (2005). 
Influence of raw meat quality and cooking procedure on gross chemical composition and technological properties:

Table (8) illustrate the effect of blanching and blanching then frying on chemical composition as well as with respect to technological qualities like cooking loss and meat cooking shrinkage and caloric value. Both of two cooking producers decreased moisture content and increased fat and protein

Table (8): Effect of cooking methods on chemical composition; technological properties and caloric value of Longissimus dorsi (LD) muscles collected from Friesian calves fed on CFM (Control) and cow's milk (MF). (\% on dry weight basis).

\begin{tabular}{|c|c|c|c|c|c|}
\hline \multirow{3}{*}{ Constituents } & \multicolumn{4}{|c|}{ Cooked meat } & \multirow{3}{*}{ Significant } \\
\hline & \multicolumn{2}{|c|}{ Blanched meat } & \multicolumn{2}{|c|}{ Fried meat } & \\
\hline & $\begin{array}{c}\text { Control } \\
\text { (CFM) }\end{array}$ & $\begin{array}{c}\text { Milk fed } \\
\text { (MF) }\end{array}$ & $\begin{array}{c}\text { Control } \\
\text { (CFM) }\end{array}$ & $\begin{array}{l}\text { Milk fed } \\
\text { (MF) }\end{array}$ & \\
\hline Moisture (\%) & $61.92^{b}$ & $63.82^{a}$ & $45.58^{d}$ & $51.37^{c}$ & $\star \star$ \\
\hline Dry matter (\%) & $38.08^{c}$ & $36.18^{d}$ & $54.42^{\mathrm{a}}$ & $48.63^{b}$ & $\star \star$ \\
\hline Crude protein (\%) & $88.80^{\mathrm{a}}$ & $88.77^{a}$ & $72.51^{d}$ & $73.15^{\mathrm{c}}$ & ** \\
\hline Ether extract (\%) & $5.72^{d}$ & $6.67^{c}$ & $23.45^{\mathrm{a}}$ & $23.39^{b}$ & $\star \star$ \\
\hline Ash content (\%) & $3.88^{c}$ & $3.56^{d}$ & $4.04^{b}$ & $4.46^{a}$ & * \\
\hline Meat cooking shrinkage (MCS) (\%) \# & $20.04^{a}$ & $19.12^{\mathrm{c}}$ & $19.50^{\mathrm{b}}$ & $18.75^{d}$ & * \\
\hline Cook loss (CLmcs) (\%) \# & $25.50^{\mathrm{a}}$ & $22.45^{\mathrm{c}}$ & $24.42^{b}$ & $21.70^{d}$ & * \\
\hline Caloric value (Kcal/100g) & $406.68^{d}$ & $415.11^{\mathrm{c}}$ & $501.09^{b}$ & $503.11^{\mathrm{a}}$ & * \\
\hline
\end{tabular}

a, b, c and d Mean by parameter in the same raw with different letters are significantly different * $P<0.05,{ }^{*}$ Significant at $P>0.01$ \# on wet weight basis.

The cooking loss is a combination of liquid and soluble matters lost from the meat during cooking. When the water content of the meat decrease the fat and protein content increase indicating that the main part of the cooking loss is water Heyman et al.( 1990). The water is probably lost due to heat induced protein denaturation during cooking of the meat, which causes less water to be entrapped within the protein structures held by capillary forces. In this study a difference was seen in cooking loss CLmcs between the two cooking procedures. Especially cooking by blanching gave a higher cooking loss compared with the blanched-fried samples. Data of Table (8) show that the MCS value of CFM $(20.04 \%$ and $19.50 \%)$ is significantly greater than MF (19.12\% and $18.75 \%)$ for blanching and blanching-frying samples respectively. These findings are agree with Scheeder et al. (1999) and Vieir et al. (2005) who observed a significant decrease in cooking losses, comparable to the degree of fat deposition.

Differences were also found between studied cooking procedures in total caloric value whereas, caloric values increased by cooking especially after frying. However, the differences were result to the changes in fat content of studied muscles as also reported by Liu et al. (1990).

\section{Organoleptic properties}

The eating quality of meat is a combination of appearance, flavor, tenderness and juiciness. Tenderness is often considered one of the major attributes of importance and several researchers have concentrated on 
understanding the basic background of tendernessWheeler et al. (2000) and Aaslyng et al.( 2003). The results suggested that juiciness experienced initially in the chewing process depended only on the water content of the meat.

In beef, it has been shown that juiciness and cooking loss are negatively correlated, implying that a high cooking loss results in low juiciness. The juiciness of meat depends on the raw meat quality and on the cooking procedure. Low water holding capacity (WHC) and low pH resulted in high cooking loss while, no difference in cooking loss was observed between meat having medium or high $\mathrm{WHC}$ and $\mathrm{pH}$ Immonen(2000) and Aaslyng et al.( 2003).

Table (9) and Fig. (1) show the mean values of the sensorial scoring of cooked meat according to kind of diet. Panelists evaluated 4 sensory attributes; flavor; color; tenderness and juiciness of freshly cooked. Scores were given to the samples on a scale of 1-5 (1minimum, 5maximum). In general, the sensory attributes were perceived by the members of the panel with low-medium intensity, with the exception of the odor and flavor characteristic of freshly cooked calf meat and tenderness. The meat was considered to be soft and juicy, leaving little residue after chewing. Statistically significant differences $(P<0.01)$ were found between CFM meat CMF meats.

Table (9): Organoleptic properties of cooked meat of Longissimus dorsi-lumborum muscle of Friesian calves fed with CFM (Control) or cow's milk.

\begin{tabular}{|l|c|c|c|c|c|}
\hline \multirow{2}{*}{\multicolumn{1}{c|}{ Treatments }} & \multicolumn{5}{c|}{ Organoliptic score\# } \\
\cline { 2 - 6 } & Flavor & Color & Tenderness & Juiciness & $\begin{array}{c}\text { Over all } \\
\text { acceptability }\end{array}$ \\
\hline CFM blanched & $4.28^{\mathrm{a}}$ & $4.25^{\mathrm{a}}$ & $3.94^{\mathrm{c}}$ & $3.82^{\mathrm{c}}$ & $4.07^{\mathrm{b}}$ \\
\hline CFM fried & $3.97^{\mathrm{c}}$ & $4.07^{\mathrm{b}}$ & $3.90^{\mathrm{d}}$ & $3.56^{\mathrm{d}}$ & $3.88^{\mathrm{d}}$ \\
\hline MF blanched & $4.15^{\mathrm{b}}$ & $3.86^{\mathrm{c}}$ & $4.42^{\mathrm{a}}$ & $4.57^{\mathrm{a}}$ & $4.25^{\mathrm{a}}$ \\
\hline MF fried & $3.75^{\mathrm{d}}$ & $3.75^{\mathrm{d}}$ & $4.00^{\mathrm{b}}$ & $4.20^{\mathrm{b}}$ & $3.93^{\mathrm{c}}$ \\
\hline Significant & ${ }^{*}$ & ${ }^{*}$ & ${ }^{*}$ & ${ }^{*}$ & \\
\hline
\end{tabular}

MF= milk fed; CFM= Concentrate feed mixture; Flavor = taste + odor divided by 2; \# Mean value obtained from 20 panelists; all properties measured on a 5-point scale (1...the lowest attribute intensity, 5...the highest intensity); General acceptability = Flavor + Color + Tenderness + Juiciness divided by4; $(P<0.05)$.

The paleness of the calf meat could be due to its low level of muscle pigments. Pigment concentration was 2-3 times lower than that found by Kesava et al., (2003).Diet also affected the sensorial quality of freshly cooked beef calf meat. Cow milk diet (MF) gave the cooked meat a more intense characteristic odor and flavor, and improved the texture of the meat. Milk odor was slightly more intense than milk flavor. The different scores recorded for odor and flavor could be related to variations in the degree of unsaturation of the fat. The development of odor and flavor in cooked meat is a complex process in which different various components react to produce intermediate or final aromatic and taste compounds. The thermal degradation of lipids plays a key role in forming the odor of cooked meat, especially in the case of unsaturated lipids, which are more reactive to heat and can, therefore, 
generate more aromatic compounds Mottram( 1998) and Dhanda et al.( 2003). Meat with higher water content is perceived as more tender and juicier, and leaves fewer residues after chewing.

Juiciness is the feeling of moisture in the mouth during chewing. It is a combination of moisture chewed out of the meat and saliva production mixed into the meat. Therefore, cooking loss and water holding capacity are obvious potential attributes to influence the juiciness. Cooking loss has often been observed to be negatively correlated to juiciness Toscas et al. (1999).

Fig. (1): Photographs of cooked meat after boiling and boiling followed by frying treatments.
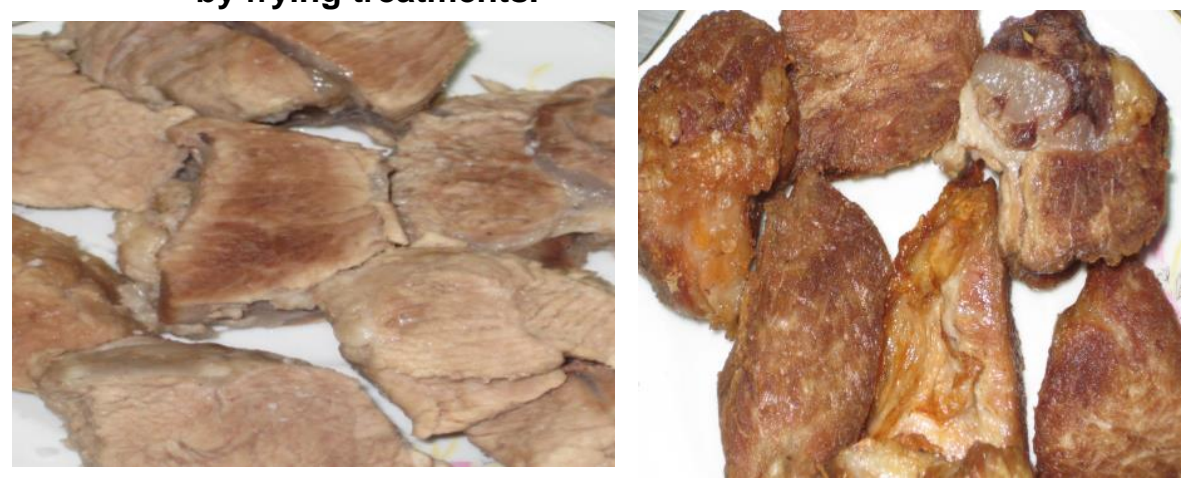

Blanched meat control (CFM) calf meat Fried control (CFM)calf meat

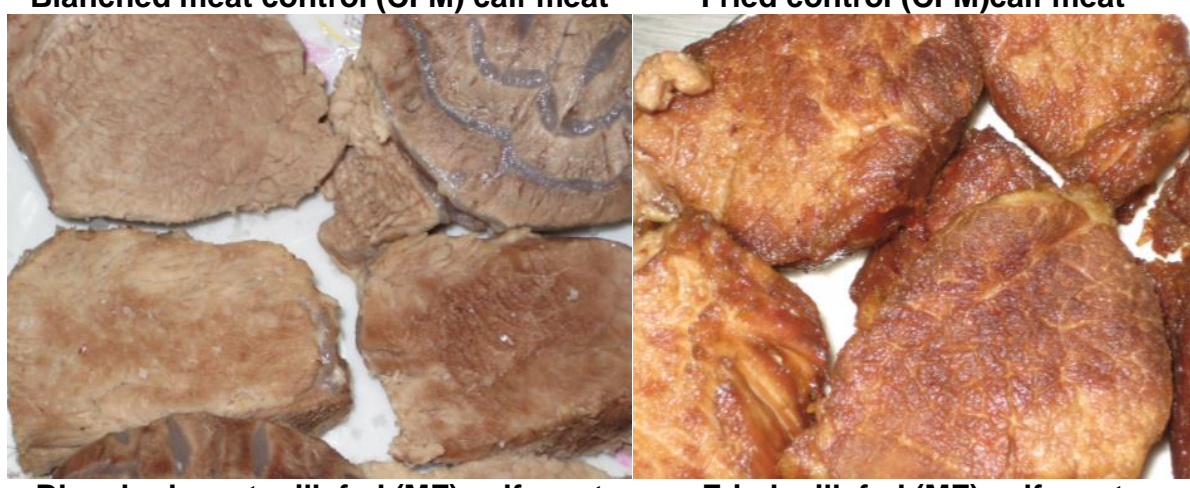

Blanched meat milk fed (MF) calf meat

Fried milk fed (MF) calf meat

Sensory analysis revealed statistically significant differences $(\mathrm{P}<0.05)$ for flavor; color; tenderness and juiciness, the highest values corresponding to the MF group. The higher percentage of intramuscular fat, shown by the Longissimus dorsi muscle of MF group, could have contributed to the higher score obtained for tenderness in sensory analysis. Thus, although indicating that intermuscular fat is only able to explain a small percentage of the variation in tenderness. The obtained results are agree with those of Nishimura et al. (1999) and Vieir et al. (2005), who reported that the presence of fat may provide an increase in subjective sensation of tenderness for the consumer. The same authors observed that true milk 
supplementation in a growing diet led to a better textured and flavored meat compared to animals where the milk was withdrawn once they began consuming solid feed.

\section{Conclusion}

Finally, it could be concluded that feeding the calves with milk, produced palatable meat, and could be an advantageous alternative in terms on meat and fat quality.

\section{REFERENCES}

Aaslyng, M. D.; Bejerholm, C.; Ertbjerg, P.; Bertram, H. C. and Andersen, H. J. (2003).Cooking loss and juiciness of pork in relation to raw meat quality and cooking procedure Food Quality and Preference 14, 277288

Abd El-Aal, H. A.; Badawy, R. M. and El-Ghazali, M. N. (2000). Proximate composition and mineral contents of fresh, deep-fat fried and microwave cooked edible fillets of six Nile fish species. Zagazig J. Agric. Res., 27, (5), $1305-1318$.

Abu El-Hamd, M. A. (2003). Rumenal development in suckling calves fed protected fat and protected protein. Ph.D. Thesis, Fac. Agric. Mansoura Univ. Egypt.

Aitken, A.; Casey, J. C.; Penny, I. F. and Voyls, C. A. (1962). Effect of drying temperature in the accelerated freeze drying of pork. J. Sci. and Fd. Agric., 13, 439.

AOAC (2000): Official Methods of Analysis of the Association of Official Analytical Chemist. $17^{\text {th }}$ ed. Washington, DC., USA.

Banón, S.; Vila, R.; Price, A.; Ferrandini, E. and Garrido, M.D. (2006). Effects of goat milk or milk replacer diet on meat quality and fat composition of suckling goat kids Meat Science 72, 216-221.

Barbera, S. and Tassone, S. (2006). Meat cooking shrinkage: Measurement of a new meat quality parameter. Meat Science, 73, 467-474.

Chambaz, A.; Scheeder, M. R. L.; Kreuzer, M and Dufey, P. A. (2003). Meat quality of angus, simmemental, charolais and limousin steers compared at the same intramuscular fat content. Meat Science, 63, 491-500.

Demeyer, D. (1999). Lipid composition in beef in relation to feeding, nutrition and technology. Proc. Of $45^{\text {th }}$ ICoMST, Yokohama, Japan, pp. 30-38.

Dhanda, J. S.; Taylor, D. G. and Murray, P. J. (2003). Carcass composition and fatty acid profiles of adipose tissue of male goats: effects of genotype and live weight at slaughter. Small Ruminant Research. 50, (1-2), 67-74.

El-Sarkawy, A, M. (2006). Effect of some growth promoters on meat production, quality and its cooking properties. Ph.D. Thesis, Fac. Of Agric., Kafrelsheikh Univ.

Erickson, D. O; Berg, P. T; Marchello, M. J. and Haugse, D. N. (1981). Selected nutritional components of beef lean. J. Anim. Sci. 53: 212. 
Heymann, H., Hedrick, H. B., Karrasch, M. A., Eggeman, M. K., and Ellersieck, M. R. (1990). Sensory and chemical characteristics of fresh pork roasts cooked to different centre temperatures. J. of Fd. Sci., 55, 613-617.

Hornick, J. L.; Clinquart, A.; Van Eanaeme, C., Diez, M., Istasse, L. (1996). Influence of whole milk in diet of growing fattening Belgian Blue bulls on animal performances and on fatty acid composition in subcutaneous, intermusclar and intramuscular fats. Livestock Prod. Sci. $48,51-58$.

Husaini, S. A.; Doartherge, F.B. and Kunkle, L. E. (1950). Studies on meat II observations on relation of biochemical factors to change in tenderness. Food Technol. 4 (9): 366-369.

Immonen, K. (2000). Bovine muscle glycogen concentration in relation to diet, slaughter and ultimate beef quality. Ph.D. thesis Univ. of Helsinki (pp. 22-25), ISBN 951-45-9495-9.

Jacobs, M. B. (1962): The chemical analysis of food and food products. $3^{\text {th }}$ ed. D. Van Nostrand company. Inc.

Jeremiah, L.E.; Gibson, J.P.; Gibson, L.L.; Ball, R.O.; Aker, C. and Fortin, A. (1999). The influence of breed, gender, and PSS (Halothane) genotype on meat quality, cooking loss, and palatability of pork. Food Research International 32, 59-7.

Kesava Rao, V., Kowale, B. N., \& Verma, A. K. (2003). Effect of feeding water washed neem (Azadirachta indica) seed kernel cake on the quality, lipid profile and fatty acid composition of goat meat. Small Ruminant Research, 47(3), 213-219.

Liu, C. W.; Huffman.; Egbert, W. X. and Lui, M. N. (1990). Effects of trimming and added connective tissue on compositional, physical and sensory properties of restructured, pre-cooked beef roasts. J. Food Sci. 55: 5.

Marichal, N., Castro, J., Capote, Zamorano, M. J., \& Argüello, A. (2003). Effects of live weight at slaughter $(6,10$ and $25 \mathrm{~kg})$ on kid carcass and meat quality. Livestock Production Science, 83(2-3), 56.

Mehany, S. B. (1999). Evaluation of some feeding systems for meat production. Ph. D. Thesis, Fac. Of Agric., Cairo Univ.

Moelich, E. I., Hoffman, L. C., \& Conradie, P. J. (2003). Sensory and functional meat quality characteristics of pork derived from three halothane genotypes. Meat Science, 63, 333-338.

Morrison, W. R. and Smith, L. M. (1964). Preparation of fatty acid methyl esters and dimethyl acetal from lipids with boron fluoride-methanol. J. Lipid Res. 5, 600-608.

Mottram, D. S. (1998). Flavor formation in meat and meat products: a review. Fd. Chem., 62: 415-424.

NRC (1996) , National Research Centre. Diet and health: implication for reducing chornic disease risk. Repot of the committee on diet and health. Food and Nutrition board. National Academy Press, Washington DC.

Nigm, A. A. (1979). The productive characteristics of Baladi carcasses with different European cattle breeds. Ph.D. Thesis, Fac. Agric., Cairo Univ. 
Nishimura, T., Hattor, A., Takahashi, K. (1999). Structural changes in intramuscular connective tissue during the fattening of Japanese Black cattle: effect of marbling on beef tenderization. J. Anim. Sci. 77, 93104.

Rao, M. V.; Gaut, N. F. S. and Kennedy, S. (1989). Variation in water holding capacity due to changes in the fiber diameter, sacromere length and connective tissue morphology of some beef muscles under acidic conditions below the ultimate $\mathrm{pH}$. Meat Science, 26: 19-37.

Scheeder, M. R. L., Becker, B., Kreuzer, M. (1999). Veal color and other meat quality characteristics in calves fattened on maize silage and concentrate. Arch. Tierz. 42 (6), 535-553.

SPSS for Windows (1997). Statistical package for the social science, Release 6, SPSS, Inc. Chcago, USA

Todaro, M., Corrao, A., Barone, C. M. A., Schinelli, R., Occidente, M., \& Giaccone, P. (2002). The influence of age at slaughter and litter size on some quality traits of kid meat. Small Ruminant Research, 44(1), 75-80.

Tornberg, E. (2005). Effects of heat on meat proteins - implications on structure and quality of meat products. Meat Science, 70, 493-508.

Toscas, P. J., Shaw, F. D., \& Beilken, S. L. (1999). Partial least squares (PLS) regression for the analysis of intrument measurements and sensory meat quality data. Meat Science, 52, 173-178.

USDA (1975). Standards for grades of carcass beef. USDA Food Safety and Quality Service, Washington DC.

Vieira, C.; García, M. D. A.; Cerdeno, and Manteco'n, A. N (2005). Effect of diet composition and slaughter weight on animal performance, carcass and meat quality, and fatty acid composition in veal calves. Livestock Prod. Sci. 93, 263-275.

Volovinskaia, V. R. and Merkolova, B. Y. (1958). Modification of the water holding capacity method of meat. Fd. Industry. Vol. 11, 80 (Moscow).

Wheeler, T. L., Shackelford, S. D., Koohmaraie, M. (2000). Relationship of beef longissimus tenderness classes to tenderness of gluteus medius, semi membranosus, and biceps femoris. J. Anim.Sci.78, 2856-2861.

Xiccato, G., Trocino, A., Queaque, P. I., Sartori., Carazzolo, A. (2002). Rearing veal calves with respect to animal welfare: effects of group housing and solid feed supplementation on growth performance and meat quality. Livest. Prod. Sci. 75, $269-280$. 
Elsanat, S. Y. et al.

تأثير التغذية بالبان الأبقار على خواص جودة لحم ودهن العجول الفريزيان و بعض

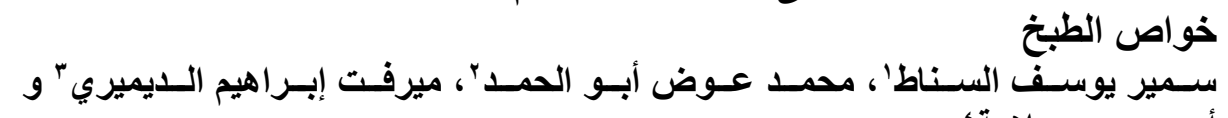

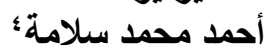

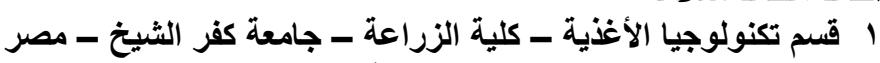

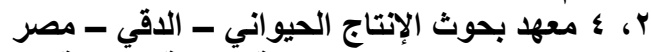
r r بم الإقتصاد المنزلي - كلية التنربية النوعية - جامعة كفر الثيخ - مصر.

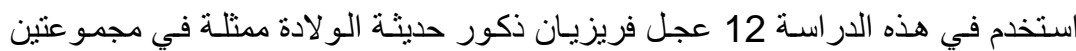

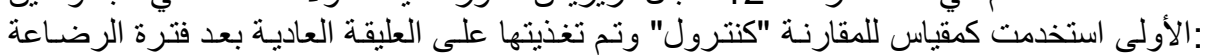

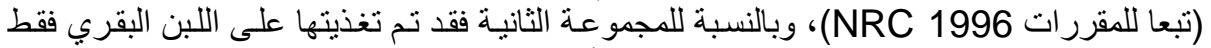

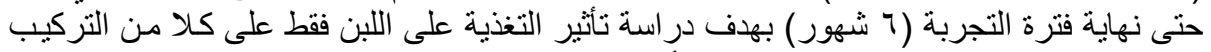

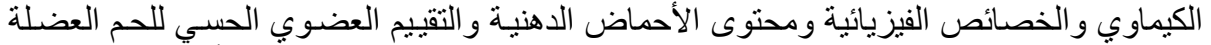

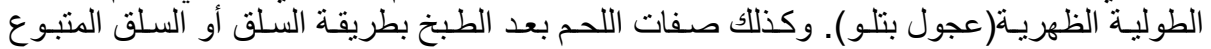

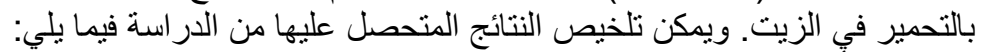

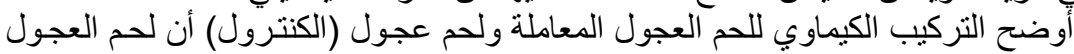

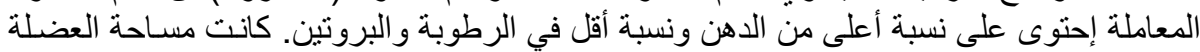

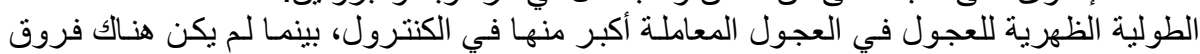

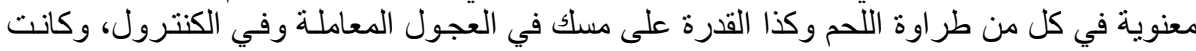

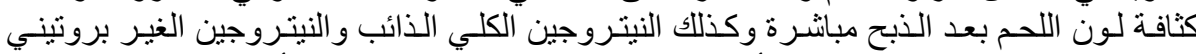

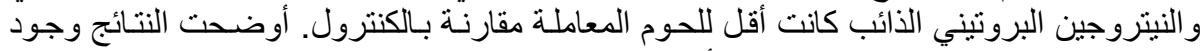

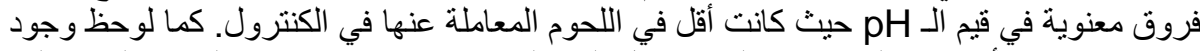

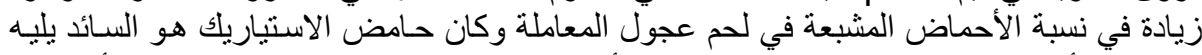

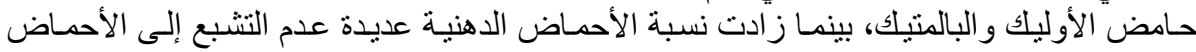

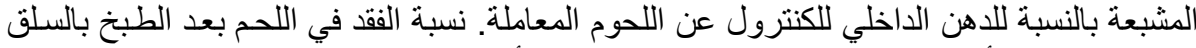

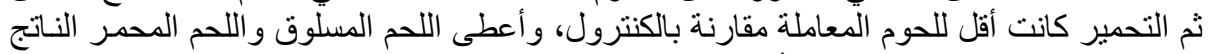

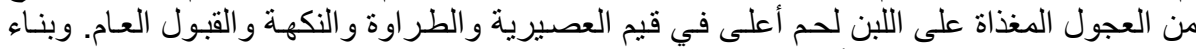

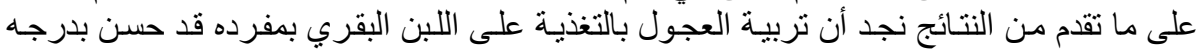
ملحوظة جودة وصفات لحم ودهون العجول الناتجة.

كلية الزراعة - جامعة المنصورة كلية الزراعة - جامعة كفر الثيخ

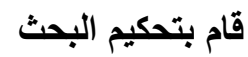

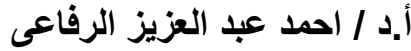

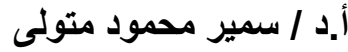

